\title{
Egne barn er ikke overvektige
}

Foreldres oppfatning av barnas vekt har endret seg de siste tiårene.

Overvekt er et økende helseproblem over hele verden, det gjelder også barn og unge. Her har foreldrene en viktig rolle. Dersom foreldrene til et overvektig barn oppfatter barnet som normalvektig, er det lite trolig at problemet får den oppmerksomhet det fortjener. I en amerikansk studie har man

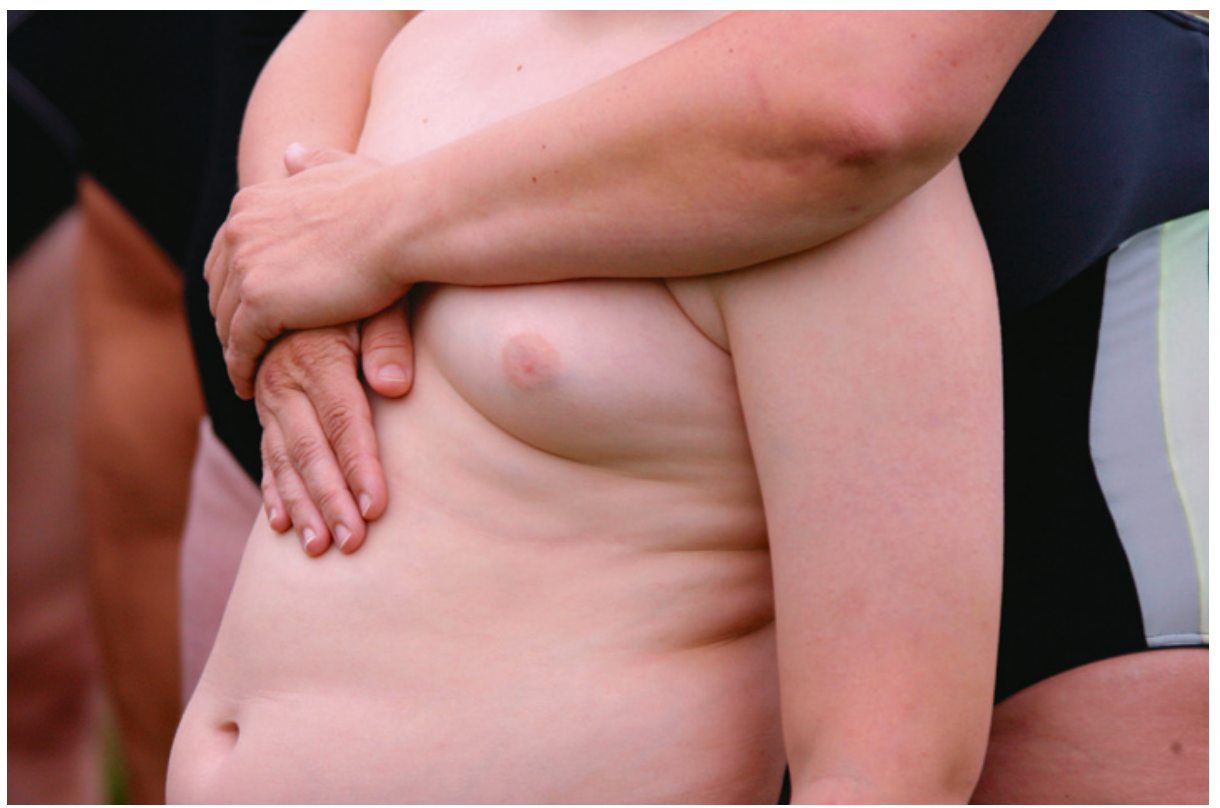

Illustrasjonsfoto: Ralf Hirschberger/NTB scanpix undersøkt foreldres oppfatning av barnas vekt og hvordan dette har endret seg fra 1988 og frem til 2010 (1).

Studien omfattet rundt 6000 barn i alderen 6-11 år, og dataene ble samlet inn i periodene 1988-94 og 2005-10. Foreldrenes oppfatning av barnas vekt ble kategorisert som

undervektig, normalvektig eller overvektig og sammenholdt med barnas kroppsmasseindeks. Av de overvektige i perioden 1988-94 ble $78 \%$ av guttene og $61 \%$ av jentene oppfattet som normalvektige av foreldrene. I perioden 2005-10 var andelen henholdsvis $83 \%$ og $78 \%$. Sannsynligheten for at overvektige barn ble oppfattet som overvektige av foreldrene sank med 24\% (sannsynlighetsratio 0,$76 ; 95 \% \mathrm{KI} 0,67-0,87)$ fra $1988-94$ til 2005-10.

- Denne studien bekrefter at foreldre til overvektige barn ofte oppfatter barnet som normalvektig, slik vi fant i en studie fra Bergen for noen år siden, sier Pétur B. Júlíusson, som er postdoktor ved Universitetet $\mathrm{i}$ Bergen og overlege ved Barneavdelingen, Haukeland universitetssykehus (2).

- Disse funnene viser hvor viktig det er å gjøre regelmessige vekt- og høydemålinger for å fange opp barn med avvikende vektutvikling på et tidlig tidspunkt. Dessuten må helsevesenet tilby hjelp til familier med barn som sliter med overvekt, sier Júlíusson.

\section{Lise Mørkved Helsingen \\ Tidsskriftet}

Litteratur

1. Hansen AR, Duncan DT, Tarasenko YN et al. Generational shift in parental perceptions of overweight among school-aged children. Pediatrics 2014; 134: $481-8$

2. Júlíusson PB, Roelants M, Markestad T et al. Parental perception of overweight and under weight in children and adolescents. Acta Paediatr 2011: 100: $260-5$

\section{Benzodiazepinbruk øker risikoen for Alzheimers sykdom}

\section{Benzodiazepiner gir $ø$ kt risiko for Alzheimers sykdom, men ikke i lave doser. Dette kan tyde på en kausal sammenheng.}

Bruk av benzodiazepiner er assosiert med øt risiko for demens, men det har ikke vært kjent om det er en kausal sammenheng. Franske og kanadiske forskere har nå undersøkt forbindelsen mellom risiko for Alzheimers sykdom og benzodiazepinbruk med oppstart minst fem år før diagnosetidspunktet (1).

Rundt 1800 personer med Alzheimers sykdom som var fulgt opp i minst seks år før diagnosetidspunktet, ble sammenliknet med over 7000 kontrollpersoner, alle over 66 år. Benzodiazepinbruk var assosiert med økt risiko for Alzheimers sykdom (justert OR 1,51; $95 \% \mathrm{KI} 1,36-1,69)$, men det var ingen risikoøkning ved bruk i lave doser. Justering også for angst, depresjon og insomni endret ikke resultatet nevneverdig.

- Flere studier har vist at benzodiazepiner gir nedsatt kognitiv funksjon, også ved kronisk bruk, sier overlege Gudrun Høiseth ved Nasjonalt folkehelseinstitutt. - Det interessante med denne studien er at den ikke viser noen sammenheng med Alzheimers sykdom ved lave doser, slik det er vist $\mathrm{i}$ andre studier når det gjelder nedsatt kognitiv funksjon hos eldre. En styrke ved studien er at forfatterne har justert for konfunderende faktorer. Det er også interessant at det ser ut til å være en dose-respons-effekt for mengde benzodiazepiner og sykdomsrisiko. Dette styrker mistanken om en kausal sammenheng. At leger bør utvise forsiktighet ved forskrivning av benzodiazepiner er ikke nytt, men studien er nok et ankepunkt for dem som er bekymret for benzodiazepinbruken, sier Høiseth.

\section{Trine B. Haugen}

Tidsskriftet

\section{Litteratur}

1. de Gage SB, Moride Y, Ducruet T et al. Benzodiazepine use and risk of Alzheimer's disease: casecontrol study. BMJ 2014; 349: g5205 